\title{
Early detection of viable Francisella tularensis in environmental matrices by culture-based PCR
}

\author{
Helen Y. Buse ${ }^{1 *}$, Brian J. Morris ${ }^{2}$ and Eugene W. Rice ${ }^{1}$
}

\begin{abstract}
Background: Francisella tularensis is a fastidious, Gram-negative coccobacillus and is the causative agent of tularemia. To assess viability yet overcome lengthy incubation periods, a culture-based PCR method was used to detect early growth of the lowest possible number of $F$. tularensis cells. This method utilized a previously developed enhanced $F$. tularensis growth medium and is based on the change in PCR cycle threshold at the start and end of each incubation.

Results: To test method robustness, a virulent Type A1 (Schu4) and B (IN99) strain and the avirulent Live Vaccine Strain (LVS) were incubated with inactivated target cells, humic acid, drinking and well water, and test dust at targeted starting concentrations of 1, 10, and $100 \mathrm{CFU} \mathrm{mL}^{-1}$ (low, mid, and high, respectively). After $48 \mathrm{~h}$, LVS growth was detected at all targeted concentrations in the presence of $10^{6}$ inactivated LVS cells; while Schu4 and IN99 growth was detected in the presence of $10^{4}$ Schu4 or IN99 inactivated cells at the mid and high targets. Early detection of F. tularensis growth was strain and concentration dependent in the presence of fast-growing well water and test dust organisms. In contrast, growth was detected at each targeted concentration by $24 \mathrm{~h}$ in humic acid and drinking water for all strains.

Conclusions: Results indicated that the culture-based PCR assay is quick, sensitive, and specific while still utilizing growth as a measure of pathogen viability. This method can circumvent lengthy incubations required for Francisella identification, especially when swift answers are needed during epidemiological investigations, remediation efforts, and decontamination verification.
\end{abstract}

Keywords: Human pathogen, Potable water, Select agent, Molecular detection, Viability, Remediation

\section{Background}

Francisella tularensis is the causative agent of tularemia, a disease with several clinical manifestations depending on the transmission route [1]. Tularemia can result from the inhalation of contaminated dust and aerosols, bites by infected vectors, contact with infected animals, or ingestion of contaminated food and water [reviewed in

\footnotetext{
*Correspondence: buse.helen@epa.gov

'US EPA, Office of Research and Development, Center for Environmental Solutions \& Emergency Response, 26 W Martin Luther King Drive NG-16, Cincinnati, OH 45268, USA

Full list of author information is available at the end of the article
}

[2]]. Although the environmental reservoir for $F$. tularensis is unclear, it has been found within rodents, lagomorphs, and arthropods [3, 4], as well as in numerous aquatic environments, e.g. surface water and sediments, brackish water, and other open water sources [5]. Contaminated surface, well, and domestic rural water, as well as community water supplies with unchlorinated or inadequate treatment processes, have all been implicated as the sources of Francisella outbreaks [reviewed in [6]] and suggests that persistence within aquatic environments may be important in Francisella ecology. 
F. tularensis is divided into three subspecies which vary in their pathogenicity and geographic distribution: tularensis (Type A), holarctica (Type B), and mediasiatica with ongoing debate whether to classify $F$. novicida, as either a fourth subspecies or separate species [7, 8]. Type A strains are further divided into two subpopulations, A1 (A.I. or A-east) and A2 (A.II. or A-west) with four distinct genotypes (A1a, A1b, A2a, and A2b) [9]. In the U.S., tularemia can be caused by both Type A and B strains with higher rates of mortality resulting from infections with A1b strains compared to A1a, A2, and Type B strains $[9,10]$.

Due to its low infectious dose, high virulence, and transmissibility by air, misuse of $F$. tularensis has the capability to cause a high-consequence event with potentially large casualties, negative effects on the economy and infrastructure, and threats to public health and safety. Therefore, F. tularensis is classified as a Tier 1 select agent by the Federal Select Agent Program, which is managed jointly by the U.S. Department of Health and Human Services and U.S. Department of Agriculture [11]. The U.S. Environmental Protection Agency (USEPA) Homeland Security Research Program provides science and technology needed for effective response and recovery from natural, intentional, or accidental environmental catastrophes, including public health threats from microbial pathogens. During these events, numerous and diverse sample types (e.g. aerosol, surface, environmental) will need to be processed and analyzed, underscoring the need for sensitive, specific, quick, and straightforward methods to determine the extent of contamination and efficacy of remediation efforts. Although culturability is a traditional indicator of viability, $F$. tularensis isolation and identification by culture is challenging because the organism is highly infectious, fastidious, slow-growing (requiring incubations of up to 10 days), difficult to identify, and can be outcompeted in culture medium by other microorganisms present in environmental or clinical samples [10]. Thus, traditional culture methods for $F$. tularensis would not meet USEPA's response and recovery needs during homeland security incidents.

Molecular detection methods such as polymerase chain reaction (PCR) cannot distinguish between culturable (potentially infectious) and inactivated pathogens since DNA from both types are present in the sample. However, features of PCR, such as rapidity, sensitivity, and specificity, can be combined with the requirement for growth in culture medium to quickly detect low concentrations of viable Francisella bacteria. Specifically, this culture-based PCR method is based on the change in PCR cycle threshold $\left(\Delta C_{\mathrm{T}}\right)$ which is calculated by subtracting the cycle threshold $\left(\mathrm{C}_{\mathrm{T}}\right)$ at time $0\left(\mathrm{C}_{\mathrm{T} 0}\right.$, i.e. starting DNA levels) from the $C_{T}$ value after incubation of samples in culture medium $\left(\mathrm{C}_{\mathrm{Ti}}\right.$, i.e. starting DNA levels in addition to those that have accumulated during the incubation): $\Delta \mathrm{C}_{\mathrm{T}}=\mathrm{C}_{\mathrm{T} 0}-\mathrm{C}_{\mathrm{Ti}}$ [12]. To help achieve the short incubation period required for early detection, an enhanced culture medium, composed of brain heart infusion broth supplemented with Vitox, Fildes, and histidine (BVFH), was previously developed for use in this method to promote early growth and enhanced cultivation of F. tularensis [13]. The method used in this study is similar to the rapid viability PCR method for detection of $F$. tularensis with the main differences being sample volumes, time points analyzed, and method of preparing the BVFH medium [14]. Other differences included the evaluation of (1) real environmental matrices (e.g. drinking water and well water), which are ecologically relevant to F. tularensis; (2) method sensitivity amidst high concentrations of inactivated target cells; and (3) more $F$. tularensis strains and PCR primer/probe sets to verify specificity and sensitivity for both Type A and B strains. These method parameters, not tested previously, would be relevant and important features during cleanup scenarios after an actual contamination event. Specifically, the bacterial Type would be unknown, high concentrations of inactivated and viable target organisms would be present, in addition to nontarget microorganisms and inhibitors found in the surrounding environment.

In this study, three Type A and B strains (Schu4, IN99, and Live Vaccine Strain [LVS]) were used to evaluate performance of this culture-based PCR method in various water matrices containing chemical and microbial challenges at low, mid, and high starting concentrations (1, 10, and $100 \mathrm{CFU} \mathrm{mL} \mathrm{m}^{-1}$ targets, respectively). Chemical challenges included humic acid and metal oxides which could negatively affect $F$. tularensis growth, recovery from water samples, and/or interfere with downstream analyses. Various concentrations of inactivated $F$. tularensis cells were used as a microbial challenge to simulate post-decontamination/remediation scenarios and to determine the minimum concentrations and length of incubations required for viable cells to overcome the PCR signals from the inactivated or unculturable cells. Other microbial challenges included indigenous organisms present in well water, drinking water, and test dust to assess potential overgrowth and negative impact on the culture-based PCR detection of $F$. tularensis.

\section{Results}

\section{Evaluation of PCR assays}

Twelve strains of Francisella spp. representing Type A1 and A2, Type B, F. novicida, and F. philomiragia were used to determine specificity of three PCR assays targeting the conserved Francisella fopA gene, Type A-specific $p d p D$ gene, and Type B-specific ISFtu2 gene. Total 
genomic DNA was isolated from each of the twelve Francisella spp. strains and quantitative PCR using cellular standards were performed for each gene assay to confirm amplicon size, specificity, and sensitivity (Table 1). In agreement with previous studies, Type A strains Schu4, F2246, H3563, and KC1482 were positive for the fopA and $p d p D$, but not the ISFtu2 PCR assays; while Type B strains LVS, IN99, KY99, OR96, and NY98 were positive for fopA and ISFtu2 but not $p d p D$ PCR assays [15-17]. Additionally, F. novicida and $F$. philomiragia were negative for all three PCR assays except for detection of the fop $A$ gene in $F$. novicida as expected from a previous report [17]. For the Type A (Schu4) and Type B (IN99 and LVS) experimental samples, no statistical differences were observed between $C_{\mathrm{T}}$ values from the fop $A$ and $p d p D$ or ISFtu 2 gene assays (data not shown); thus, $\mathrm{C}_{\mathrm{T}}$ values from the fop $A$ gene assay were used and $\Delta C_{\mathrm{T}}$ calculated as described in the Methods.

\section{Detection of $F$. tularensis in the presence of inactivated target cells}

Inactivated target cells were generated by incubation in isopropanol for use in determining the minimum concentrations and length of incubations required for viable cells to overcome the PCR signals from their inactivated counterparts. Control wells containing 0 , $10^{2}, 10^{4}$, or $10^{6}$ of the inactivated IN99 and Schu4 cells, analyzed at $0,8,24$, and $48 \mathrm{~h}$, confirmed that these cells were not viable and that no change in
PCR signal was observed over time (SFigure). In Fig. 1, data from the low, mid, and high targeted starting concentrations of 1,10 , and 100 colony forming units (CFU) $\mathrm{mL}^{-1}$ are shown in blue, red, and black, respectively; and within each of those groups, open circles, squares, triangles, and diamonds represent samples that contained $0,10^{2}, 10^{4}$, and $10^{6}$ of inactivated cells, respectively. The actual starting concentrations (mean CFU $\mathrm{mL}^{-1} \pm$ standard deviation [SD]) for strain IN99 were $3 \pm 1,26 \pm 9$, and $187 \pm 77$; and for strain Schu4 were $\leq 1,8 \pm 0$, and $45 \pm 7$ for the low, mid, and high targets, respectively (Table 2 ). Actual starting concentrations for strain LVS was not performed. However, for each of the three targets, strains LVS, IN99, and Schu4 displayed expected CFU increases after 8,24 , and $48 \mathrm{~h}$ of incubation indicating growth was not inhibited in the presence of their respective inactivated cells (Fig. 1 a, e, and i). Because the actual titer of Schu4 was $\leq 1$ for the low target, viable Schu4 cells may not have been inoculated into the wells of the 48-h plate containing $10^{2}$ inactivated Schu4 cells (Fig. 1 i, blue square, < limit of detection (LOD) of $1 \log _{10} \mathrm{CFU} \mathrm{mL} \mathrm{mL}^{-1}$ for all three replicates).

At the $100 \mathrm{CFU} \mathrm{mL}^{-1}$ target, a $\Delta \mathrm{C}_{\mathrm{T}} \geq 6$ was achieved by $24 \mathrm{~h}$ in LVS and Schu 4 samples containing $\leq 10^{4}$ inactivated cells (Fig. $1 \mathrm{~b}$ and $\mathrm{j}$, respectively), except for IN99 where the mean $\Delta C_{\mathrm{T}(\mathrm{T} 0 \text { - T24) }} \pm \mathrm{SD}$ in the presence of $10^{4}$ inactivated cells was $3.6 \pm 0.6$ (Fig. $1 \mathrm{f}$, black open triangle). By $48 \mathrm{~h}$, only strain LVS displayed the $\Delta C_{T} \geq 6$ for all samples (Fig. 1b), while

Table 1 Francisella spp. strains and specificity of PCR assays used in this study

\begin{tabular}{|c|c|c|c|c|c|}
\hline Francisella spp. strain & Description & Source & fopA (87 bp) & pdpD (104 bp) & ISFtu2 (118 bp) \\
\hline \multicolumn{6}{|c|}{ F. tularensis subsp. tularensis Type A } \\
\hline Schu4 & Clinical isolate, Ohio, Type A1 strain & Laura Rose, CDC & + & + & - \\
\hline F2246 & Maryland isolate, Type A1 strain & Laura Rose, CDC & + & + & - \\
\hline H3563 & Oklahoma isolate, Type A1 strain & Laura Rose, CDC & + & + & - \\
\hline KC1482 & Utah isolate, Type A2, attenuated & Laura Rose, CDC & + & + & - \\
\hline \multicolumn{6}{|c|}{ F. tularensis subsp. holarctica Type B } \\
\hline LVS & Live vaccine strain, attenuated & Laura Rose, CDC & + & - & + \\
\hline IN99 & Indiana isolate & Laura Rose, CDC & + & - & + \\
\hline NY98 & Clinical isolate, New York & Laura Rose, CDC & + & - & + \\
\hline OR96 & Oregon isolate & Laura Rose, CDC & + & - & + \\
\hline KY99 & Kentucky isolate & Laura Rose, CDC & + & - & + \\
\hline F. novicida strain U112a & Environmental isolate, saltwater & BEl Resources & + & - & - \\
\hline F. philomiragia strain 25,015 & Isolated from moribund muskrat, Utah & ATCC & - & - & - \\
\hline F. philomiragia strain 25,018 & Water isolate, Odgen Bay Refuge, Utah & ATCC & - & - & - \\
\hline
\end{tabular}

CDC Centers for Disease Control and Prevention, USA

ATCC American Type Culture Collection, USA

${ }^{a}$ The following isolate was obtained through the NIH Biodefense and Emerging Infections Research Resources Repository, NIAID, NIH: Francisella novicida, Strain Utah 112, NR-13

PCR amplicon/signal " + " detected or "-" not detected. Data are representative of three replicates

Sensitivity for each assay based on standard curves was 10 cell equivalents per $\mathrm{mL}$ 


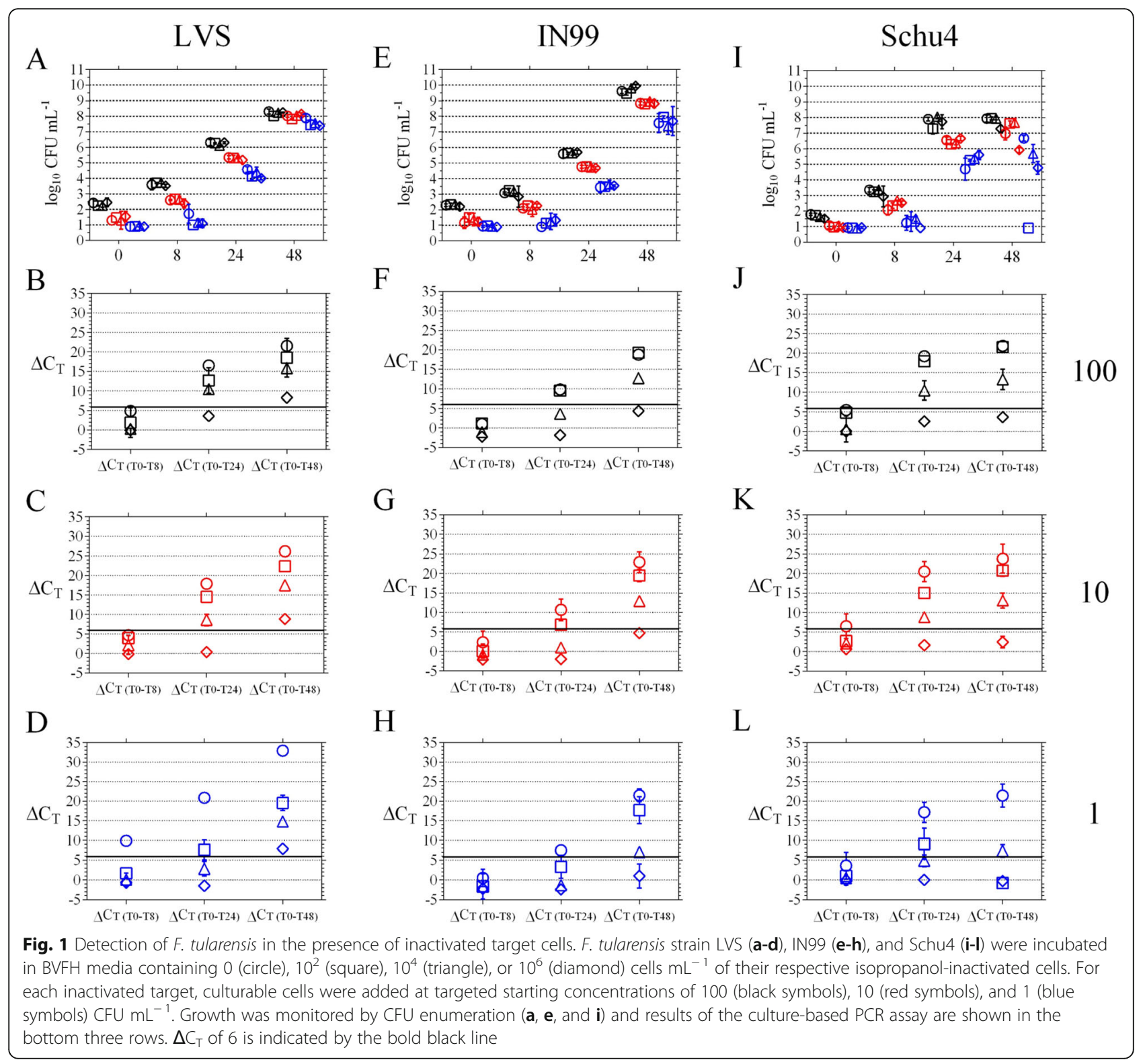

strain IN99 and Schu4 had a mean $\Delta \mathrm{C}_{\mathrm{T}(\mathrm{T} 0-\mathrm{T} 48)} \pm \mathrm{SD}$ of $4.4 \pm 1.2$ and $3.7 \pm 0.6$ in the presence of $10^{6}$ inactivated target cells but $\Delta C_{T} \geq 6$ for all other samples (Fig. $1 \mathrm{f}$ and $\mathrm{j}$ ).

The same trend was observed at the $10 \mathrm{CFU} \mathrm{mL} \mathrm{m}^{-1} \mathrm{tar}$ get where the $\Delta C_{T} \geq 6$ was achieved by $24 \mathrm{~h}$ in the LVS and Schu4 samples (Fig. $1 \mathrm{c}$ and $\mathrm{k}$, respectively) containing $\leq 10^{4}$ inactivated cells and not for IN99, where the mean $\Delta \mathrm{C}_{\mathrm{T} \text { (T0-T24) }} \pm \mathrm{SD}$ in the presence of $10^{4}$ inactivated cells was $1.0 \pm 0.3$ (Fig. 1g, red open triangle). By $48 \mathrm{~h}$, only strain LVS displayed the $\Delta C_{T} \geq 6$ for all samples (Fig. 1c), while strain IN99 and Schu4 had a mean $\Delta C_{\mathrm{T} \text { (T0-T48) }} \pm \mathrm{SD}$ of $4.7 \pm 0.3$ and $2.4 \pm 1.5$ in the presence of $10^{6}$ inactivated target cells but $\Delta C_{T} \geq 6$ for all other samples (Fig. $1 \mathrm{~g}$ and $\mathrm{k}$ ).
As expected, for the initial target concentration of 1 $\mathrm{CFU} \mathrm{mL} L^{-1}$, a longer incubation period was needed to overcome the PCR signal detected from the inactivated target cells. A $\Delta C_{\mathrm{T}} \geq 6$ at $24 \mathrm{~h}$ could not be achieved in samples containing $>10^{2}$ inactivated target cells for LVS and Schu4 (Fig. $1 \mathrm{~d}$ and l, respectively) while the $\Delta \mathrm{C}_{\mathrm{T}} \geq$ 6 was only observed for IN99 samples in the absence of inactivated cells (Fig. 1h, blue open circle). After $48 \mathrm{~h}$, $\Delta C_{\mathrm{T}} \geq 6$ was achieved for all LVS samples (Fig. 1d) and for IN99 samples containing $\leq 10^{4}$ inactivated cells (Fig. $1 \mathrm{~h})$ in contrast to Schu4 where the $\Delta C_{\mathrm{T}} \geq 6$ was only achieved in the presence of $10^{4}$, but not $10^{2}$, inactivated cells (Fig. 11) most likely due to the low starting inoculum where certain samples may not have received any viable Schu4 cells (Table 2). 
Table 2 F. tularensis actual and targeted starting concentrations for each experiment

\begin{tabular}{|c|c|c|c|c|c|c|c|c|c|c|c|c|c|c|c|c|}
\hline \multirow{5}{*}{$\begin{array}{l}\text { Experiment } \\
\text { Inactivated target cells }\end{array}$} & \multirow{5}{*}{$\begin{array}{l}\text { Strain } \\
\text { LVS }\end{array}$} & \multicolumn{15}{|c|}{ Actual Starting Concentrations for each Targeted Concentration } \\
\hline & & \multirow{2}{*}{\multicolumn{5}{|c|}{$\frac{\text { Low }}{1 \mathrm{CFU} \mathrm{mL}}$}} & \multirow{2}{*}{\multicolumn{5}{|c|}{$\frac{\mathrm{Mid}}{10 \mathrm{CFU} \mathrm{mL}^{-1}}$}} & \multirow{2}{*}{\multicolumn{5}{|c|}{$\frac{\text { High }}{100 \mathrm{CFU} \mathrm{mL}^{-1}}$}} \\
\hline & & & & & & & & & & & & & & & & \\
\hline & & \multicolumn{3}{|c|}{ Replicates } & \multirow[t]{2}{*}{ mean } & \multirow[t]{2}{*}{ SD } & \multicolumn{3}{|c|}{ Replicates } & \multirow[t]{2}{*}{ mean } & \multirow[t]{2}{*}{ SD } & \multicolumn{3}{|c|}{ Replicates } & \multirow[t]{2}{*}{ mean } & \multirow[t]{2}{*}{ SD } \\
\hline & & - & - & - & & & - & - & - & & & - & - & - & & \\
\hline & IN99 & 2 & 4 & 2 & 3 & 1 & 20 & 36 & 22 & 26 & 9 & 193 & 260 & 107 & 187 & 77 \\
\hline & Schu4 & $<1$ & $<1$ & 1 & - & - & 8 & 8 & 8 & 8 & 0 & 48 & 51 & 37 & 45 & 7 \\
\hline \multirow[t]{3}{*}{ Humic Acid } & LVS & 3 & 1 & 2 & 2 & 1 & 20 & 15 & 20 & 18 & 3 & 147 & 140 & 227 & 171 & 48 \\
\hline & IN99 & $<1$ & $<1$ & $<1$ & - & - & 2 & 2 & $<1$ & - & - & 17 & 9 & 7 & 11 & 5 \\
\hline & Schu4 & 2 & 2 & 1 & 2 & 1 & 27 & 31 & 20 & 26 & 6 & TNTC & TNTC & TNTC & - & - \\
\hline \multirow[t]{3}{*}{ Arizona Test Dust } & LVS & 1 & 1 & 1 & 1 & 0 & 13 & 13 & 15 & 14 & 1 & 51 & 67 & 94 & 71 & 22 \\
\hline & IN99 & - & - & - & - & - & - & - & - & - & - & - & - & - & - & - \\
\hline & Schu4 & - & - & - & - & - & - & - & - & - & - & - & - & - & - & - \\
\hline \multirow[t]{3}{*}{ Well Water } & LVS & $<1$ & $<1$ & $<1$ & - & - & 5 & 4 & 4 & 4 & 1 & 31 & 23 & 21 & 25 & 5 \\
\hline & IN99 & 1 & 1 & 2 & 1 & 1 & 10 & 15 & 12 & 12 & 3 & 61 & 73 & 83 & 72 & 11 \\
\hline & Schu4 & 1 & 1 & 1 & 1 & 0 & 12 & 11 & 13 & 12 & 1 & 123 & 107 & 103 & 111 & 11 \\
\hline \multirow[t]{3}{*}{ Drinking Water } & LVS & 1 & 1 & 1 & 1 & 0 & 15 & 13 & 13 & 14 & 1 & 39 & 46 & 90 & 58 & 28 \\
\hline & IN99 & 4 & 4 & 4 & 4 & 0 & 33 & 42 & 46 & 40 & 7 & 287 & 400 & 300 & 329 & 62 \\
\hline & Schu4 & $<1$ & 1 & $<1$ & - & - & 9 & 8 & 7 & 8 & 1 & 41 & 47 & 41 & 43 & 3 \\
\hline
\end{tabular}

"-", not performed

TNTC too numerous to count

\section{F. tularensis detection in the presence of environmental inhibitors \\ Humic acid}

Humic acid was used as a surrogate for natural organic matter to test for possible inhibition of $F$. tularensis growth and downstream PCR analyses. In these experiments, actual starting concentrations (mean CFU $\mathrm{mL}^{-1}$ $\pm \mathrm{SD}$ ) for strain LVS were $2 \pm 1,18 \pm 3$, and $171 \pm 48$ CFU $\mathrm{mL}^{-1}$ for the low, mid, and high targets, respectively (Table 2). For strain IN99, the starting inoculum was approximately $1 \log _{10}$ unit lower for the low, mid, and high targets displaying ranges of $<1,<1$ to 2 , and $7-17$, respectively (Table 2 ). CFU could not be enumerated for Schu4 at the high target due to overgrowth; however, the mean CFU mL $\mathrm{mL}^{-1} \pm \mathrm{SD}$ actual starting concentrations for the 1 and $10 \mathrm{CFU} \mathrm{mL} \mathrm{mL}^{-1}$ target were $2 \pm 1$ and $26 \pm 6 \mathrm{CFU} \mathrm{mL} \mathrm{mL}^{-1}$, respectively (Table 2 ).

Growth of F. tularensis strains LVS and Schu4 was not inhibited in the presence of $50 \mu \mathrm{g} \mathrm{mL}^{-1}$ humic acid since CFU levels were not statistically different between their respective control and humic acid treated samples at each targeted starting concentration $(P>0.05$, Fig. 2a, circle and triangle symbols). This observation was also true for strain IN99 at the high target $(P>0.05$, Fig. 2a, open and filled black squares). Due to the low starting concentrations of IN99, it was possible that no cells were inoculated into some of the wells at the 1 and $10 \mathrm{CFU}$ $\mathrm{mL}^{-1}$ targets potentially giving false positives for humic acid inhibition of IN99 cell growth (Fig. 2a, circled data points). Furthermore, after 24 and $48 \mathrm{~h}$ of incubation for the $10 \mathrm{CFU} \mathrm{mL} \mathrm{m}^{-1}$ target, the control IN99 samples had a mean $\log _{10} \mathrm{CFU} \mathrm{mL} \mathrm{mL}^{-1} \pm \mathrm{SD}$ concentration of $3.7 \pm 0.2$ and $6.0 \pm 0.4$, respectively (Fig. $2 \mathrm{a}$, open red squares); while the 48-h incubated IN99 with humic acid samples had CFU levels of $5.6 \pm 0.3$ (Fig. 2a, filled red square) indicating growth of IN99 was not inhibited by humic acid.

Using the culture-based PCR method, a $\Delta C_{T} \geq 6$ was achieved following $24 \mathrm{~h}$ of incubation for LVS and Schu4 at each targeted starting concentration (Fig. 2 b-d, circle and triangle symbols, respectively) and for strain IN99 at the mid and high targets (Fig. 2 b and c, filled squares). Like the growth trends observed for strain IN99 at the 1 CFU $\mathrm{mL}^{-1}$ target, the potential exclusion of viable IN99 cells into the samples may have resulted in an observed $\Delta C_{T}<6$, which could be a false positive indicator of humic acid inhibition (Fig. 2d, open and filled squares).

\section{Arizona test dust}

Arizona Test Dust (ATD) was used as an additional environmental test matrix to further evaluate F. tularensis detection with the culture-based PCR method. Strains IN99 and Schu4 were unable to be tested due to time and logistical constraints with the BSL-3 facility; thus, only the reference LVS strain was used for the ATD test matrix experiments. For LVS, actual CFU densities 


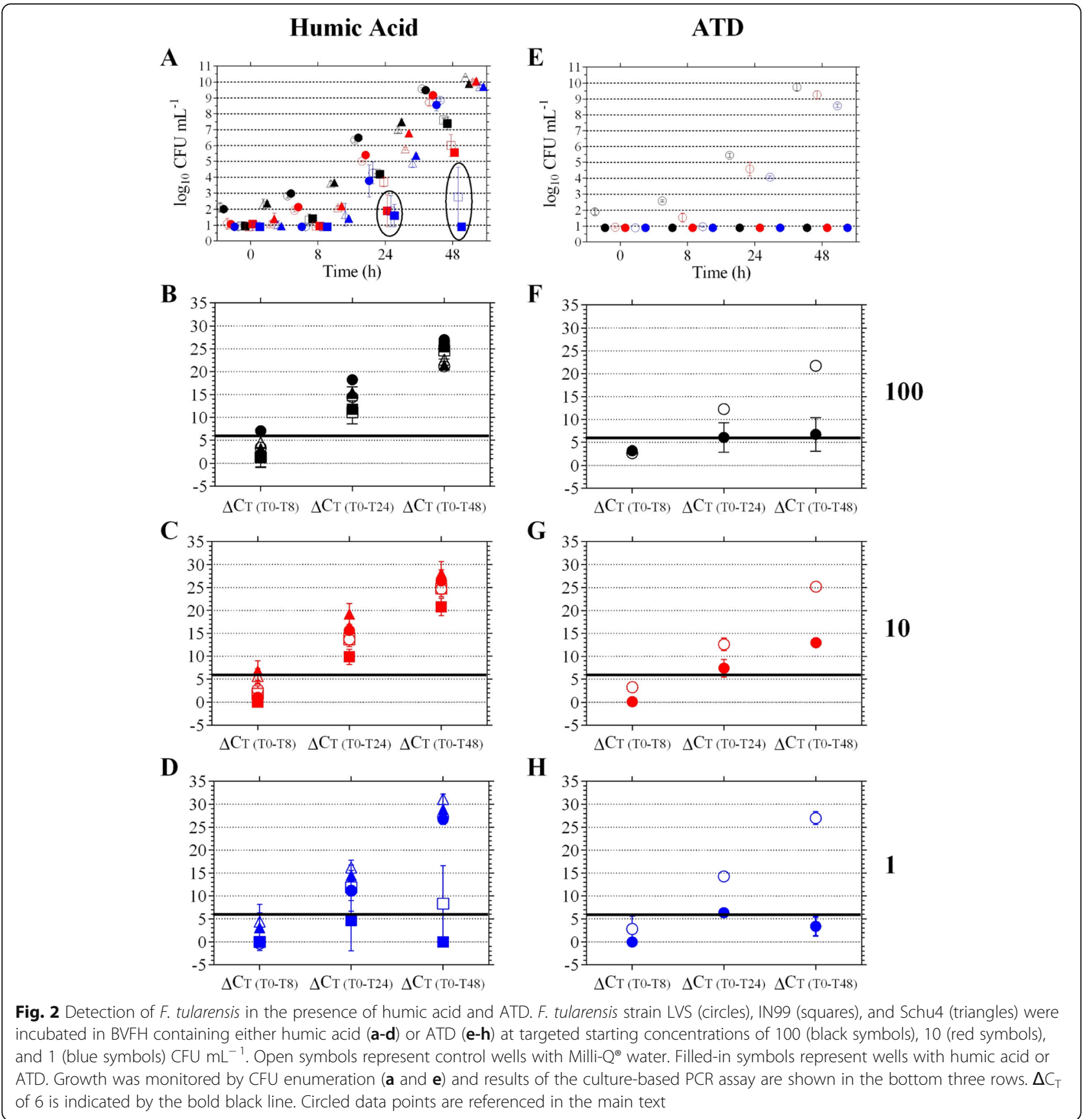

(mean CFU $\pm \mathrm{SD}$ ) were $1 \pm 0,14 \pm 1,71 \pm 22$, and for the low, mid, and high targeted starting concentrations, respectively, for each replicate (Table 2). For the samples containing ATD, LVS CFU levels were $<$ limit of detection (LOD) because ATD background organisms overgrew the agar plate and $F$. tularensis colonies could not be identified (Fig. 2e, filled in symbols).

Fig. $3 \mathrm{a}$ and $\mathrm{b}$ show images of ATD microorganisms after incubation in BVFH media for 0 and $48 \mathrm{~h}$, respectively. At $0 \mathrm{~h}$, heterogeneous colony morphologies with various types of form, elevation, and margin was observed (Fig. 3a). In contrast, by $48 \mathrm{~h}$, growth was dominated by a homogeneous mixture of microbes exhibiting large spreading colonies at high concentrations (Fig. 3b). ATD microbes exhibited rapid growth in the BVFH medium, with concentrations (mean $\log _{10} \mathrm{CFU} \mathrm{mL} \mathrm{mL}^{-1} \pm$ SD) of $3.6 \pm 0.0$ at $0 \mathrm{~h} ; 7.1 \pm 0.6$ at $24 \mathrm{~h}$; and $7.8 \pm 0.3$ at $48 \mathrm{~h}$. It is unclear from the culture data if ATD microbes inhibited LVS or masked their growth on agar plates. However, PCR results showed significantly lower levels of LVS in the presence of ATD compared to controls indicating that LVS growth was inhibited or outcompeted 


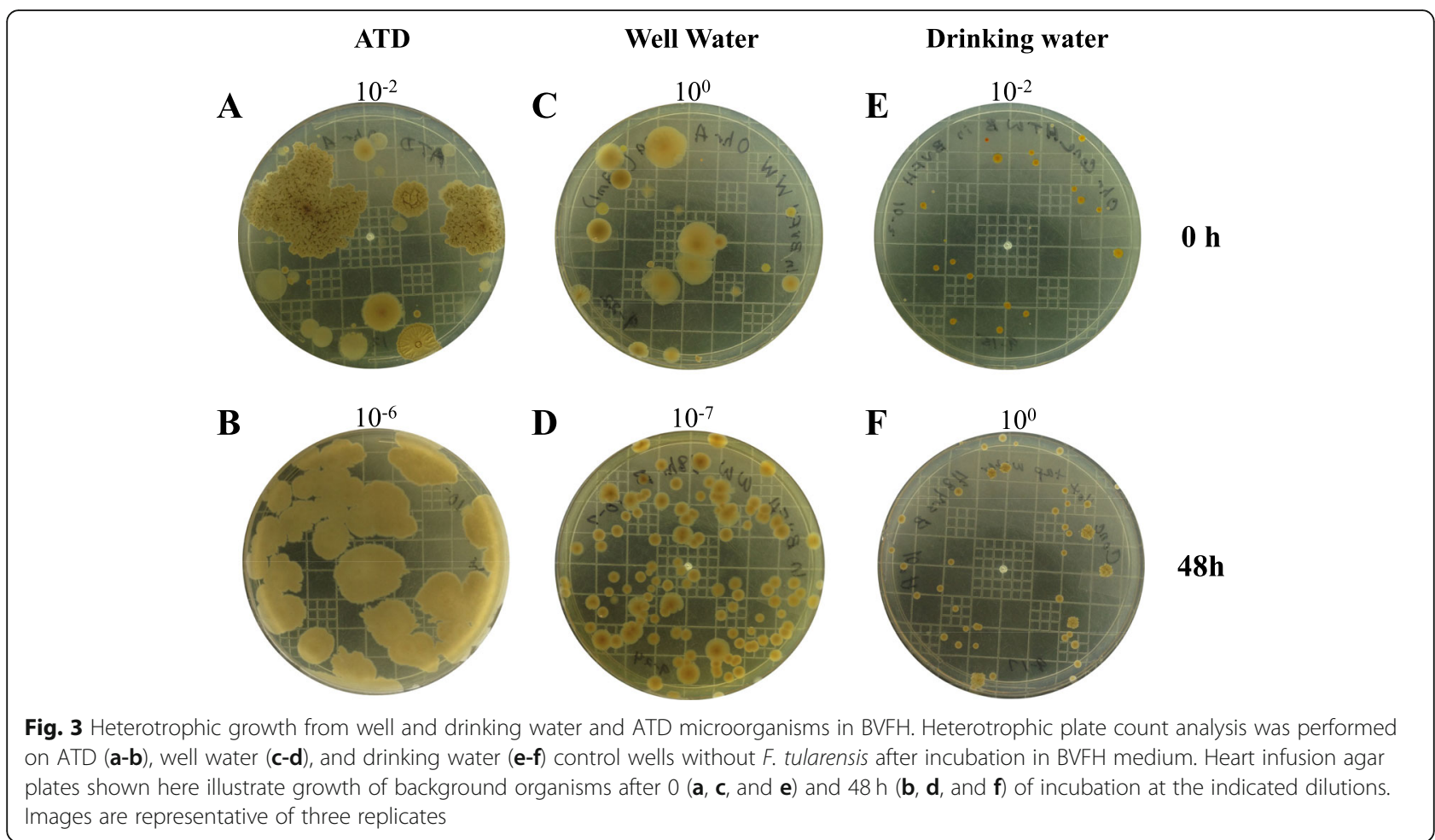

in the presence of ATD microbes (Fig. $2 \mathrm{f}-\mathrm{h}, P<0.05$, open versus filled in symbols at 24 and $48 \mathrm{~h}$ ).

Although LVS growth was not detectable, the $\Delta C_{T} \geq 6$ was achieved in this experiment after $24 \mathrm{~h}$ for each targeted starting concentration (Fig. $2 \mathrm{f}$-h). Although the $\Delta C_{T} \geq 6$ was achieved by $24 \mathrm{~h}$, the $\Delta \mathrm{C}_{\mathrm{T}}$ did not significantly increase by $48 \mathrm{~h}$, for the mid and high targets, indicating growth of the LVS cells was compromised in the presence of ATD. At the $100 \mathrm{CFU} \mathrm{mL} \mathrm{m}^{-1}$ target, $\Delta \mathrm{C}_{\mathrm{T}} \pm \mathrm{SD}$ values for the ATD containing samples at 24 and $48 \mathrm{~h}$ were $6.1 \pm 3.2$ and $6.8 \pm 3.6$, respectively (Fig. 2f, filled black circles). Similarly, at the $10 \mathrm{CFU} \mathrm{mL}{ }^{-1}$ target, $\Delta \mathrm{C}_{\mathrm{T}} \pm$ SD values for the ATD containing samples at 24 and $48 \mathrm{~h}$ were $7.4 \pm 1.9$ and $13.0 \pm 0.8$, respectively (Fig. $2 \mathrm{~g}$, filled red circles). At the $1 \mathrm{CFU} \mathrm{mL}{ }^{-1}$ target, the $\Delta \mathrm{C}_{\mathrm{T}} \geq 6$ was achieved at $24 \mathrm{~h}$ but not at $48 \mathrm{~h}$ (mean $\Delta \mathrm{C}_{\mathrm{T}} \pm \mathrm{SD}$ of $6.3 \pm$ 1.2 and $3.4 \pm 2.1$, respectively, Fig. $2 \mathrm{~h}$ ) indicating that inhibition or suppression of LVS growth by ATD microorganisms may be concentration dependent.

\section{Effect of indigenous microorganisms on F. tularensis detection in various water matrices}

Since contaminated water sources have been implicated in tularemia outbreaks, well water and drinking water were used as additional environmental test matrices to evaluate the culture-based PCR method for F. tularensis detection. Microbial and chemical water quality data are presented for each well and drinking water experiment using strains LVS, IN99, and Schu4 (Table 3). Heterotrophic plate count
(HPC) bacteria in well and drinking water ranged between $1.6-3.2$ and $<$ LOD to $3.2 \log _{10} \mathrm{CFU} \mathrm{mL} \mathrm{m}^{-1}$, respectively. Total coliforms and Escherichia coli levels in the well water ranged between 24 to 3650 and $<1$ to 34 most probable number (MPN) per $100 \mathrm{~mL}$, respectively (Table 3 ).

Among the chemical parameters measured, $\mathrm{pH}$, temperature, conductivity, hardness, and silicon concentrations were statistically different between the two test water matrices (Table $3, P<0.01$ ) and most likely alkalinity as well, but this parameter was not measured for the Schu4 experiments, thus statistical analysis could not be performed. Well and drinking water HPC bacteria displayed heterogeneous colony morphologies at $0 \mathrm{~h}$ (Fig. $3 \mathrm{c}$ and e, respectively); however, by $48 \mathrm{~h}, \mathrm{HPC}$ growth was comprised of a less diverse subset of microbes with well water HPC bacteria growing to high concentrations (Fig. 3d, $10^{-7}$ dilution of well water versus Fig. 3 f, $10^{\circ}$ dilution of drinking water). Similar to the ATD microbes, those in well water exhibited rapid growth in the BVFH medium reaching high CFU concentrations by $48 \mathrm{~h}$. Specifically, well water HPC levels (mean $\log _{10} \mathrm{CFU} \mathrm{mL} \mathrm{mL}^{-1} \pm \mathrm{SD}$ ) after 0,24 , and $48 \mathrm{~h}$ of growth were $1.7 \pm 0.3,8.2 \pm 0.2$, and $9.0 \pm 0.2$, respectively, compared to drinking water HPC levels of $3.3 \pm$ $0.4,1.8 \pm 0.2$, and $2.8 \pm 0.3$ at the same time points.

\section{Well water}

Actual starting densities (mean CFU \pm SD) for strain LVS were $<1,4 \pm 1$, and $25 \pm 5$; for IN99 were $1 \pm 1,12 \pm 3$, and 
Table 3 Water quality measurements for well water and drinking water

\begin{tabular}{|c|c|c|c|c|c|c|c|c|c|c|}
\hline \multirow[t]{2}{*}{ Parameters $^{a}$} & \multicolumn{5}{|c|}{ Well Water experiments } & \multicolumn{5}{|c|}{ Drinking water experiments } \\
\hline & LVS & IN99 & Schu4 & mean & SD & LVS & IN99 & Schu4 & mean & SD \\
\hline HPC $\left(\log _{10} C F U \mathrm{~mL}^{-1}\right)$ on HIA & 3.2 & 2.1 & 1.6 & 2.3 & 0.8 & 3.3 & 3.4 & 2.1 & 2.9 & 0.7 \\
\hline Total Coliforms (MPN $100 \mathrm{~mL}^{-1}$ ) & 3.6 & 1.6 & 1.4 & 2.2 & 1.2 & - & - & - & - & - \\
\hline E. coli (MPN $\left.100 \mathrm{~mL}^{-1}\right)$ & 34 & $<1$ & $<1$ & - & - & - & - & - & - & - \\
\hline $\mathrm{pH}^{\mathrm{b}}$ & 7.39 & 7.27 & 7.57 & 7.41 & 0.15 & 8.39 & 8.17 & 8.54 & 8.37 & 0.19 \\
\hline temperature $\left({ }^{\circ} \mathrm{C}\right)^{\mathrm{b}}$ & 12.0 & 11.0 & 11.0 & 11.33 & 0.58 & 37.46 & 36.33 & 36.88 & 36.89 & 0.57 \\
\hline conductivity $\left.(\mu \mathrm{S} \mathrm{cm})^{-1}\right)^{b}$ & 747 & 765 & 759 & 757 & 9 & 393 & 497 & 479 & 456 & 56 \\
\hline turbidity (NTU) & 2.31 & 0.49 & 0.18 & 0.99 & 1.15 & 0.37 & 0.93 & 0.40 & 0.57 & 0.32 \\
\hline DO (\%) & 89.9 & 72.3 & 77.0 & 79.73 & 9.11 & 59.4 & 59.6 & 64.6 & 61.20 & 2.95 \\
\hline TOC & 1.0 & 0.5 & 18.6 & 6.7 & 10.3 & 0.7 & 0.5 & 0.6 & 0.6 & 0.1 \\
\hline hardness $^{\mathrm{b}}$ & 460 & 410 & 462 & 444 & 29 & 171 & 188 & 170 & 176 & 10 \\
\hline alkalinity & 324 & 259 & - & - & - & 87 & 93 & 93 & 91 & 4 \\
\hline Free $\mathrm{Cl}_{2}$ & $<0.02$ & $<0.02$ & $<0.02$ & - & - & 0.02 & 0.02 & 0.12 & 0.05 & 0.06 \\
\hline Total $\mathrm{Cl}_{2}$ & 0.02 & 0.02 & 0.02 & 0.02 & 0.00 & 0.08 & 0.07 & 0.24 & 0.13 & 0.10 \\
\hline $\mathrm{NO}_{3}$ & 0.82 & 0.93 & 1.00 & 0.92 & 0.09 & 0.74 & 0.47 & 0.51 & 0.57 & 0.15 \\
\hline $\mathrm{PO}_{4}$ & 0.15 & 0.05 & 0.67 & 0.29 & 0.33 & 0.24 & 0.29 & 0.34 & 0.29 & 0.05 \\
\hline $\mathrm{Ca}$ & 281.8 & 115.8 & 114.7 & 170.8 & 96.2 & 30.7 & 36.4 & 36.5 & 34.5 & 3.3 \\
\hline $\mathrm{Cu}$ & $<0.001$ & $<0.001$ & $<0.001$ & - & - & 0.05 & 0.08 & 0.04 & 0.06 & 0.02 \\
\hline $\mathrm{Fe}$ & 0.09 & 0.03 & 0.02 & 0.05 & 0.04 & 0.07 & 0.14 & 0.05 & 0.09 & 0.05 \\
\hline K & 2.2 & 1.8 & 1.8 & 1.9 & 0.2 & 2.3 & 3.0 & 2.9 & 2.8 & 0.4 \\
\hline $\mathrm{Mg}$ & 13.8 & 15.3 & 14.6 & 14.6 & 0.7 & 9.3 & 13.2 & 12.6 & 11.7 & 2.1 \\
\hline $\mathrm{Na}$ & 7.1 & 7.8 & 7.7 & 7.5 & 0.4 & 18.5 & 29.4 & 27.9 & 25.3 & 5.9 \\
\hline$P$ & 0.04 & 0.02 & 0.01 & 0.03 & 0.02 & 0.10 & 0.16 & 0.15 & 0.14 & 0.03 \\
\hline $\mathrm{Si}^{\mathrm{b}}$ & 4.6 & 5.0 & 4.9 & 4.8 & 0.2 & 2.7 & 1.8 & 2.1 & 2.2 & 0.5 \\
\hline $\mathrm{Zn}$ & 0.79 & 0.05 & 0.09 & 0.31 & 0.41 & 0.03 & 0.05 & 0.02 & 0.03 & 0.01 \\
\hline
\end{tabular}

Abbreviations: $\mu \mathrm{S} \mathrm{cm-1} \mathrm{microSiemens} \mathrm{per} \mathrm{centimeter,} \mathrm{HIA} \mathrm{heart} \mathrm{infusion} \mathrm{agar,} \mathrm{MPN} \mathrm{most} \mathrm{probable} \mathrm{number,} \mathrm{NTU} \mathrm{Nephelometric} \mathrm{Turbidity} \mathrm{Units,} \mathrm{SD}$

standard deviation

"-", not performed

a units are $\mathrm{mg} \mathrm{L}^{-1}$ unless stated otherwise

${ }^{b} P<0.01$ between well and drinking water samples. Unpaired t-tests were performed for each parameter except total coliforms, $E$. coli, free and total $\mathrm{Cl}_{2}$, and $\mathrm{Cu}$

$72 \pm 11$; and for Schu4 were $1 \pm 0,12 \pm 1$, and $111 \pm 11$ for the low, mid, and high targets, respectively (Table 2). For samples containing well water, CFU levels for all three $F$. tularensis strains were $<$ LOD because well water microbes overgrew the agar plate and F. tularensis colonies could not be identified (Fig. 4a, filled in symbols). In contrast, control samples containing sterilized well water (sWW), growth of strains IN99 and Schu4 was observed at 8, 24, and $48 \mathrm{~h}$ in a starting concentration dependent manner as expected (Fig. 4, open squares for IN99 and triangles for Schu4, with the low, mid, and high targets shown in blue, red, and black, respectively). Except for the $24 \mathrm{~h}$ time point at the 1 and $10 \mathrm{CFU} \mathrm{mL}{ }^{-1}$ target, LVS cells displayed the same growth pattern throughout the time course (Fig. 4a, missing red and blue open circles at $24 \mathrm{~h}$, but present at all other time points). Those $24 \mathrm{~h}$ CFU values could not be determined due to the dehydration of agar plates for a subset of the serially diluted samples while the remaining subset were contaminated with morphologically different colonies than those observed with the LVS in well water samples.

For control, sWW samples, a $\Delta \mathrm{C}_{\mathrm{T}} \geq 6$ was observed at 24 and $48 \mathrm{~h}$ for each strain at all targeted starting concentrations (Fig. 4 b-d open symbols). However, for strains LVS and IN99 in the well water samples, the mean $\Delta \mathrm{C}_{\mathrm{T}}$ was $<6$ and ranged from -3.8 to 3.1 for LVS and -1.6 to 5.8 for IN99 for all targeted concentrations and time points (Fig. 4 b-d, filled circles and squares). Notably, for strain Schu4, a $\Delta C_{T}>6$ was observed at $24 \mathrm{~h}$ for the high (mean $\Delta C_{T} \pm S D$, $12.5 \pm 4.0)$ and mid $(12.6 \pm 0.7)$ targets and by $48 \mathrm{~h}$ for the low target (17.5 \pm 6.7 ) (Fig. 4 b-d, filled triangles). Moreover, although actual starting concentrations between strain IN99 and Schu4 were not statistically different at the low and mid targets $(P>0.3$, Table 2$), \Delta \mathrm{C}_{\mathrm{T}(\mathrm{T} 0-\mathrm{T} 48)}$ values were statistically different between the two strains (Fig. $4 \mathrm{c}-\mathrm{d}, * P<0.05$ ) collectively indicating that early detection of $F$. tularensis in well water type matrices may be strain dependent. 


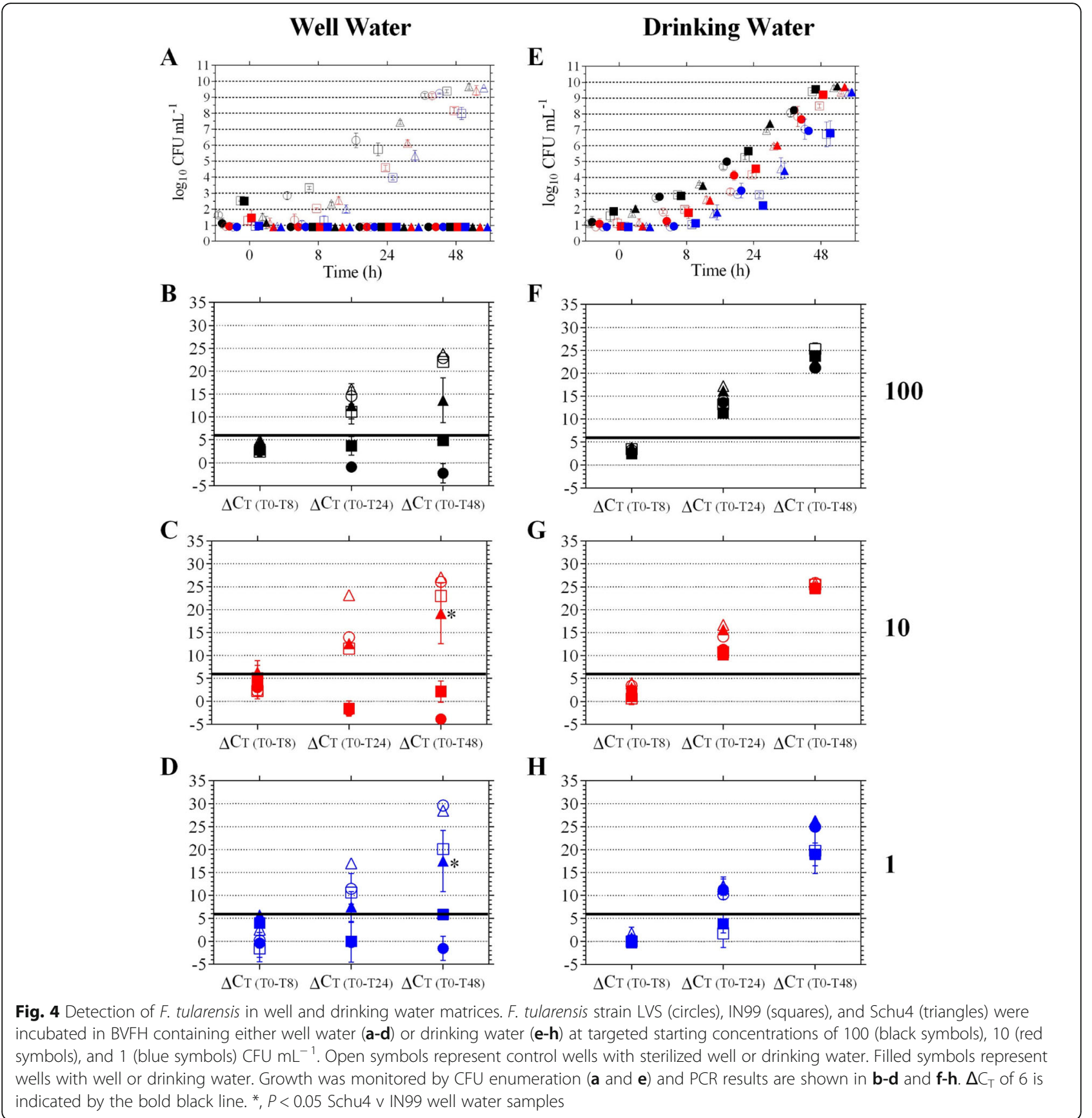

\section{Drinking water}

In contrast to well water, drinking water microorganisms did not significantly amplify in the BVFH medium (mean $\log _{10} \mathrm{CFU} \mathrm{mL}^{-1} \pm \mathrm{SD}: 3.3 \pm 0.4$ at $0 \mathrm{~h}$ vs $2.8 \pm$ 0.3 at $48 \mathrm{~h}, P>0.05$ and Fig. $3 \mathrm{~d}$ vs $3 \mathrm{f}$ ). In the absence of fast growing HPC organisms, growth of strains LVS, IN99, and Schu4 was observed in the presence of drinking water in a starting concentration dependent manner as expected (Fig. 4e). Moreover, there were no statistical differences between CFU levels in the sterilized drinking water (sDW) controls and the levels of each strain in their respective drinking water samples at each targeted starting concentration and time point $(P>0.05$, Fig. 4e). Actual starting densities (mean $\mathrm{CFU} \pm \mathrm{SD}$ ) for strain LVS were $1 \pm 0,14 \pm 1$, and $58 \pm 28$; for IN99 were $4 \pm 0$, $40 \pm 7$, and $329 \pm 62$; and for Schu4 were $<1$ to $1,8 \pm 1$, and $43 \pm 3$ for the low, mid, and high targeted concentrations, respectively (Table 2 ).

The mean $\Delta \mathrm{C}_{\mathrm{T}(\mathrm{T} 0 \text {-T24) }} \pm \mathrm{SD}$ at the 100,10 , and $1 \mathrm{CFU}$ $\mathrm{mL}^{-1}$ targeted dose was, respectively, $13.6 \pm 0.5,11.3 \pm$ 0.4 , and $11.3 \pm 1.1$ for strain LVS; $16.2 \pm 0.4,15.7 \pm$ In the absence of fast growing HPC0.9, and $11.4 \pm 2.2$ for 
strain Schu4; and $11.3 \pm 0.6,10.2 \pm 0.3$, and $3.8 \pm 3.3$ for strain IN99 (Fig. $4 \mathrm{f}$-h). Thus, the $\Delta \mathrm{C}_{\mathrm{T}} \geq 6$ was achieved following $24 \mathrm{~h}$ of incubation in the presence of drinking water for each strain at each targeted dose, except for strain IN99 at the $1 \mathrm{CFU} \mathrm{mL}{ }^{-1}$ target (Fig. $4 \mathrm{~h}$, open and filled blue squares, control and drinking water samples, respectively). Because the sDW controls were also below the $\Delta C_{\mathrm{T}}$ of 6 and lower IN99 CFU levels were observed at the $24 \mathrm{~h}$ time point compared to LVS and Schu4 (Fig. $4 \mathrm{e}$, blue squares vs blue circles and triangles, respectively), the $\Delta \mathrm{C}_{\mathrm{T}}<6$ was most likely not due to inhibition of IN99 growth in the drinking water matrix. By $48 \mathrm{~h}$, a $\Delta \mathrm{C}_{\mathrm{T}(\mathrm{T} 0-\mathrm{T} 48)} \pm \mathrm{SD}$ of $19.0 \pm 4.3$ at the low target was observed for strain IN99 (Fig. 4h, filled blue square).

\section{Discussion}

In this study, the criteria used for early detection of $F$. tularensis growth is based on the change in PCR cycle threshold $\left(\Delta \mathrm{C}_{\mathrm{T}}\right)$ which is calculated by subtracting the cycle threshold $\left(\mathrm{C}_{\mathrm{T}}\right)$ at time $0\left(\mathrm{C}_{\mathrm{T} 0}\right.$, i.e. starting DNA levels) from the $C_{T}$ value after incubation of samples in culture medium $\left(\mathrm{C}_{\mathrm{Ti}}\right.$, i.e. starting DNA levels in addition to those resulting from growth of viable cells): $\Delta \mathrm{C}_{\mathrm{T}}=$ $\mathrm{C}_{\mathrm{T} 0}-\mathrm{C}_{\mathrm{Ti}}$. For detection of $F$. tularensis cells, a $\Delta \mathrm{C}_{\mathrm{T}}$ value $\geq 6$ was chosen to indicate growth of viable cells during the incubation period and was similarly used as a criterion for early detection of Bacillus anthracis and Yersinia pestis growth [12, 18]. It should be noted that this $\Delta C_{T}$ nomenclature is different from the one commonly used in gene expression studies employing the comparative $C_{\mathrm{T}}$, or $2^{-\Delta \Delta C T}$, method where $\Delta \mathrm{C}_{\mathrm{T}}$ is the difference in threshold cycle between target and reference genes within the same sample [19].

Various $F$. tularensis PCR assays were tested for use in this method. The fopA gene encodes an outer membrane associated protein, $p d p D$ encodes the pathogenicity determinant protein $\mathrm{D}$, and ISFtu 2 encodes a multiple copy, insertion element-like sequence $[15,16]$. The $p d p D$ gene lies within a putative operon consisting of $p d p D i g l A B C D$ and encodes a $140.7-\mathrm{kDa}$ membraneassociated protein that is required for virulence but not intracellular growth [20, 21]. However, in $F$. tularensis subsp. holarctica (Type B) strains, most of the $p d p D$ gene is missing or absent and may play a role in the difference in virulence between Type A and B strains [22]. The assay for the $p d p D$ gene is absent from Type B strains and contains a $144 \mathrm{bp}$ insert in $F$. novicida strains [15] which was verified in this study (Table 1). No statistical differences were observed for $C_{T}$ values collected from the fop $A$ and $p d p D$ assays for Schu4 and between the fopA and ISFtu2 assays for IN99 and LVS samples $\left(P>0.05\right.$, data not shown); thus, for consistency, $C_{\mathrm{T}}$ values from the fopA PCR assay were reported and analyzed here for strains Schu4, IN99, and LVS.
To evaluate performance under conditions mimicking post-decontamination scenarios, the culture-based PCR method was tested in the presence of low titers of viable target cells and high levels of inactivated target cells which may be present after remediation efforts. Although different results were obtained for each strain, the overall trend indicated the assay can detect growth of 1 viable cell $\mathrm{mL}^{-1}$ by $48 \mathrm{~h}$ in the presence of up to $10^{4}$ inactivated cells $\mathrm{mL}^{-1}$ for strain IN99 and Schu4 (Fig. $1 \mathrm{~h}$ and l, respectively) and up to $10^{6}$ inactivated cells $\mathrm{mL}^{-1}$ for strain LVS (Fig. 1d). Moreover, at low inactivated background levels of $10^{2}-10^{4}$ cells $\mathrm{mL}^{-1}$, a $\Delta C_{\mathrm{T}} \geq 6$ was achieved for all strains after $24-48 \mathrm{~h}$ incubation in BVFH. However, for low titers of live target cells in the presence of high levels of inactivated target cells, an incubation period $>48 \mathrm{~h}$ may be needed to observe a $\Delta \mathrm{C}_{\mathrm{T}} \geq 6$ yet would still be less time required for identification using traditional culture methods.

Humic acids are reported to bind DNA in a sequencespecific manner, thus limiting the amount of template DNA available for the PCR reaction [23]. Due to the difficulty in measuring humic acid concentrations directly in water matrices, their concentrations are usually estimated from total organic carbon (TOC) or dissolved organic carbon (DOC) measurements. An Indiana-based study monitored DOC concentrations over a 22-month period in river water before and after conventional drinking water treatment and found DOC concentrations to range between 2 and $12 \mu \mathrm{gL}^{-1}$ in river water and $1-4 \mu \mathrm{g} \mathrm{mL}^{-1}$ in chloraminated, finished water [24]. Thus, even if humic acids constituted a majority of the DOC, the humic acid concentration evaluated in this study, $50 \mu \mathrm{g} \mathrm{mL}^{-1}$, was between 4 and 50 times higher than levels reported for surface and finished drinking water samples. Thus, the evaluation of this high concentration of humic acid in this study represented a worstcase scenario of the possible concentration and carryover of environmental inhibitors into samples for processing and downstream molecular analyses. Without prior removal of the humic acid from DNA extracted samples, PCR reactions were inhibited (data not shown). Thus, these samples required a clean-up step after DNA isolation, after which PCR results were not statistically different from controls with no humic acid $(P>0.05$, Fig. $2 \mathrm{~b}-\mathrm{d}$ ). For this chemical challenge, results from the method indicated the $\Delta C_{T} \geq 6$ was achieved following $24 \mathrm{~h}$ of incubation for LVS and Schu4 at each targeted starting concentration and for strain IN99 at the mid and high targets (Fig. 2 b-d). Collectively, despite the issues with the IN99 inoculum, the method was able to detect early amplification of $F$. tularensis in the presence of humic acid after $24 \mathrm{~h}$ of incubation.

Arizona test dust (ATD) is commonly used as a surrogate for atmospheric particles, soil, and household dust 
due to its consistent particle size distribution and chemical and biological composition [25-27]. Thus, ATD was used as a test matrix for its representation of environmental challenges possibly encountered during environmental sampling and effects on the culture-based PCR method. In the $4 \mathrm{mg} \mathrm{mL}^{-1}$ ATD concentration used in this study and based on the lowest composition percentages of the metal oxides or ions (i.e. $10 \% \mathrm{Al}_{2} \mathrm{O}_{3}, 2 \%$ $\mathrm{Fe}_{2} \mathrm{O}_{3}$, and $0.51 \% \mathrm{TiO}_{2}$ ), the ATD samples contained $210 \mu \mathrm{g} \mathrm{mL}^{-1}$ of $\mathrm{Al}, 56 \mu \mathrm{g} \mathrm{mL}^{-1}$ of $\mathrm{Fe}$, and $20 \mu \mathrm{g} \mathrm{mL}^{-1}$ of $\mathrm{TiO}_{2}$, which is approximately $25-400$ times above the PCR inhibitory levels previously reported for each inhibitor $[28,29]$. Moreover, silicon, the main constituent of ATD $\left(68-76 \% \mathrm{SiO}_{2}\right.$ ) was previously reported to inhibit PCR by interfering with Taq polymerase [30]. Thus, similar to humic acid, ATD samples required a clean-up step for extracted DNA prior to PCR analysis in order to remove the multiple PCR inhibitors contained within ATD (data not shown).

In addition to chemical challenges, previous microbial analysis of ATD indicated a composition of yeast, molds, actinomycetes, Bacillus spp., Micrococcus spp., and Streptomyces spp. with HPC concentrations of 4.6 $\log _{10}$ CFU $10 \mathrm{mg}^{-1}$ on Reasoner's 2A agar (R2A) [31], which was approximately $1 \log _{10}$ higher than levels observed in this study $\left(3.6 \pm 0.06 \log _{10}\right.$ CFU $10 \mathrm{mg}^{-1}$ on R2A, Methods Section). In this study, CFU enumeration of LVS was not possible in the presence of fast-growing, competing ATD microbes (Fig. 2e, filled circles $\mathrm{v}$ control, open circles). Moreover, although a mean $\Delta C_{\mathrm{T}} \geq 6$ was observed for LVS at each targeted starting dose, method performance was concentration dependent since mean $\Delta C_{T} \pm S D$ values at $24 \mathrm{~h}$ decreased by $48 \mathrm{~h}$ at the low target (Fig. $2 \mathrm{~h}$, filled circles $6.3 \pm 1.2$ to $3.4 \pm 3.1$, respectively) and only increased slightly from 24 to $48 \mathrm{~h}$ at the high target (Fig. 2f, filled circles, $6.1 \pm 3.2$ to $6.8 \pm 3.6$, respectively). Nonetheless, the culture-based PCR method was able to detect LVS growth after $24 \mathrm{~h}$ of incubation demonstrating the specificity and sensitivity of PCR analysis amidst a high interfering background and negative results from traditional culture methods.

Similarly, for the well water test matrix, $F$. tularensis CFU densities could not be quantified at 8,24 , and $48 \mathrm{~h}$ post incubation due to the rapid growth of well water microbes (Fig. 4a). Acid pretreatment of environmental samples has been shown to reduce interference by indigenous microbes and enhance recovery of $F$. tularensis from natural water samples [32, 33]. However, no significant differences in HPC densities were observed between acid treated well water samples and non-treated controls (mean $\log _{10} \mathrm{CFU} \mathrm{mL} \mathrm{mL}^{-1} \pm \mathrm{SD}: 0.642 \pm 0.11$ and $0.635 \pm$ 0.37 , respectively on heart infusion agar (HIA); $P=0.6$; four replicates each). Although the fast-growing, competing microbes negatively affected growth and enumeration of $F$. tularensis in the well water samples, the culture-based PCR method detected early growth of the Type A1 Schu4 strain, in contrast to the Type B strains LVS and IN99 (Fig. 4 b-d).

Although the persistence and growth in natural waters for both types have been previously reported [reviewed in [6]], it is unknown whether environmental growth fitness and survival mechanisms differ between Type A and B strains. Infections with Type A1 strains result in higher mortality rates compared to Type $\mathrm{A} 2$ and Type $\mathrm{B}$ strains $[9,34]$. Thus, virulence mechanisms present in Schu4, but absent in LVS and IN99, could confer a growth/survival advantage as potentially observed in the well water experiments where only Schu4 growth was detected amongst a high background of competing microbes (Fig. 4 b-d). For future culture-based PCR method studies, more avirulent and virulent $F$. tularensis Type A and B strains should be further tested in the well water and ATD matrices to confirm this interesting observation of potentially strain dependent fitness to compete with fast-growing microbes.

The occurrence of coliform bacteria in chlorinated systems was reported to be significantly higher at temperatures above $15{ }^{\circ} \mathrm{C}$ than at $0-15^{\circ} \mathrm{C}$ [35]. Thus, to assess the performance of the culture-based PCR assay for $F$. tularensis in the presence of drinking water microorganisms, warm tap water $\left(36.9 \pm 0.6^{\circ} \mathrm{C}\right.$, Table 3$)$ was concentrated 100-fold to collect a high titer of indigenous drinking water microbes. Their presence in the BVFH medium neither inhibited nor outcompeted $F$. tularensis growth (Fig. 4e) and did not negatively affect the early detection of $F$. tularensis using the culture-based PCR assay (Fig. $4 \mathrm{f}$-h).

\section{Conclusions}

In this study, a culture-based PCR method was able to detect early growth of low levels of $F$. tularensis cells amongst high levels of their respective inactivated target cells and various environmental interferences and inhibitors. Results also indicated that indigenous drinking water organisms were not capable of growth in nutrient rich medium (e.g. BVFH), unlike those in ATD and well water. Thus, this method could also be used to detect early growth of other water-based pathogens, such as $L e$ gionella pneumophila, where drinking water is an important source of human exposure [36]. The culturebased PCR method evaluated in this study can be used as an alternative to traditional culture methods for detection and identification of fastidious pathogens by combining the rapidity, sensitivity, and specificity of PCR with culturability as an indicator of microbial viability. 


\section{Methods}

\section{Bacterial strains and growth conditions}

Table 1 lists the bacterial strains used in this study. Stock and stationary phase cultures of Francisella spp. were prepared as previously described by Morris et al. [13]. For the test conditions described below, F. tularensis strains LVS, IN99, and Schu4 were grown in a previously developed enhanced growth medium, BVFH, for Francisella spp., which consisted of brain heart infusion broth (Becton Dickinson [BD] Biosciences, USA) supplemented with $2 \%$ Vitox $^{\mathrm{TM}}$ (Oxoid Hampshire UK), 10\% Fildes (Remel, USA), and 1\% ${ }_{\mathrm{L}}$-histidine (Fisher Scientific, USA) [13]. Experiments with virulent F. tularensis strains were conducted under biosafety level 3 (BSL-3) conditions at the University of Cincinnati College of Medicine with protocols approved by the university's Institutional Biosafety Committee and the Select Agent Program.

\section{Colony forming units (CFU) enumeration}

To determine Francisella spp. densities, an aliquot of the bacterial suspension was serially diluted in Butterfield's buffer (BB; $42.5 \mathrm{mg}$ monopotassium phosphate $\mathrm{L}^{-1}$; Hardy Diagnostics, USA) and plated on chocolate agar plates (BD Biosciences, USA). Plates were incubated for 48 h [for spot plate method [37, 38]] or 4-7 d [for spread plate method [39]] at $37^{\circ} \mathrm{C}$. The spot plate method was used for evaluation of high CFU titers at later time points. The limit of detection (LOD) was 1 and $1.95 \log _{10}$ CFU $\mathrm{mL}^{-1}$, for the spread and spot plate method, respectively.

Heterotrophic plate count (HPC) bacteria were enumerated by the spread plate method on heart infusion agar (HIA, Difco Laboratories) following incubation at $35^{\circ} \mathrm{C}$ for $7 \mathrm{~d}$ or Reasoner's $2 \mathrm{~A}$ agar (R2A, Difco Laboratories) following incubation at $28^{\circ} \mathrm{C}$ for $7 \mathrm{~d}$. The LOD was $1 \log _{10} \mathrm{CFU} \mathrm{mL} \mathrm{m}^{-1}$. For untreated well water samples only, total coliforms and Escherichia coli were measured using Colilert ${ }^{\oplus}$ (Idexx Laboratories, USA) following manufacturer's protocols.

\section{Preparation of $\boldsymbol{F}$. tularensis cell suspensions}

Bacterial cultures were grown in triplicate for each strain to stationary phase, washed by centrifugation (3000 relative centrifugal force [RCF] for $10 \mathrm{~min}$ at $4{ }^{\circ} \mathrm{C}$ ), and stored in $\mathrm{BB}$ for $24 \mathrm{~h}$ at $4{ }^{\circ} \mathrm{C}$. These resting cells were used as the inoculum to more closely mimic the physiological state of planktonic cells in the natural aquatic environment [40]. Suspensions were enumerated for CFU and the concentrations before and after incubation at $4{ }^{\circ} \mathrm{C}$ were not statistically different $(P>0.05$, STable). Resting cells cultures were diluted in BVFH to yield approximate suspensions of 15,150 , and $1500 \mathrm{CFU} \mathrm{mL}^{-1}$ and for use in experiments, these suspensions were diluted 15-fold in the various matrices to achieve targeted starting concentrations of 1,10 , and $100 \mathrm{CFU} \mathrm{mL}^{-}$ 1 , respectively. Actual starting concentrations are listed in Table 2 and were enumerated by spread plating $200 \mu \mathrm{L}$ onto five separate chocolate agar plates (BD Biosciences, USA) resulting in a LOD of 1 CFU $\mathrm{mL}^{-1}$.

\section{Collection of water samples}

Potable municipal drinking water samples were collected from laboratory taps and were derived from river water treated by coagulation/flocculation/sedimentation, rapid sand filtration, granular activated carbon filtration, and chlorination. Ten liters were concentrated by filtration through a $0.45 \mu \mathrm{m}$ polycarbonate filter (GE Osmonics, USA) and resulted in a $100 \mathrm{~mL}$ volume of 100 -fold concentrated drinking water. A $1 \mathrm{~mL}$ aliquot of a $10 \%(\mathrm{w} / \mathrm{v})$ sodium thiosulfate (Sigma-Aldrich, USA), prepared using distilled water, was added to the concentrate to neutralize disinfectant residuals.

Well water samples were collected on a private farm from a well supplying nonpotable ground water from a deep aquifer. The well water pump was operated for a few minutes before two $1 \mathrm{~L}$ samples were collected in sterile collection bottles. Water temperature was recorded right after sampling with a sterilized thermometer. Samples were kept at $4{ }^{\circ} \mathrm{C}$ for up to $4 \mathrm{~h}$ before transport to the laboratory. A $10 \mathrm{~mL}$ portion of the drinking and well water was filtered through a $0.1 \mu \mathrm{m}$ Supor $^{\oplus}$ (hydrophilic polyethersulfone) membrane Acro$\operatorname{disc}^{\ominus}$ syringe filter (Pall Corporation, USA) resulting in sterilized drinking water (sDW) and well water (sWW) for use as controls.

\section{Preparation of humic acid and Arizona test dust (ATD)}

A $750 \mu \mathrm{g} \mathrm{mL}^{-1}$ solution of humic acid was prepared using Milli-Q ${ }^{\bullet}$ water (EMD Millipore, USA) and was added to samples at a final concentration of $50 \mu \mathrm{g} \mathrm{mL}^{-1}$. Arizona test dust (ATD, Powder Technologies Inc., USA) was chemically composed of $68-76 \% \mathrm{SiO}_{2}, 10$ $15 \% \mathrm{Al}_{2} \mathrm{O}_{3}, 2-5 \% \mathrm{CaO}, 2-5 \% \mathrm{Fe}_{2} \mathrm{O}_{3}, 2-5 \% \mathrm{~K}_{2} \mathrm{O}, 2-4 \%$ $\mathrm{Na}_{2} \mathrm{O}, 1-2 \% \mathrm{MgO}$, and $0.5-1 \% \mathrm{TiO}_{2}$. Previously published analysis of ATD indicated a microbial composition consisting of yeast, molds, actinomycetes, Bacillus spp., Micrococcus spp., and Streptomyces spp. and HPC concentrations of 3.9, 4.6 and $4.7 \log _{10}$ CFU per $10 \mathrm{mg}$ on Sabouraud dextrose agar, R2A, and Trypticase soy agar plus 5\% sheep blood, respectively [31]. In this study, heterotrophic plate count (HPC) bacteria in ATD was $3.9 \pm 0.05$ and $3.6 \pm 0.06 \log _{10}$ CFU $10 \mathrm{mg}^{-1}$ on HIA and $\mathrm{R} 2 \mathrm{~A}$, respectively. A $60 \mathrm{mg} \mathrm{mL}^{-1}$ solution of ATD was prepared using Milli- $\mathrm{Q}^{\bullet}$ water and was added to samples at a final concentration of $4 \mathrm{mg} \mathrm{mL}^{-1}$. 


\section{Preparation of inactivated $F$. tularensis cell suspensions}

For each $F$. tularensis strain, static cultures were pelleted and washed twice by centrifugation at $3000 \mathrm{rcf}$ for 10 min at $21^{\circ} \mathrm{C}$ with $25 \mathrm{~mL}$ of $\mathrm{BB}$. Aliquots of the suspensions were incubated in either $\mathrm{BB}$ (for controls) or $70 \%$ isopropanol (for inactivation) at $21^{\circ} \mathrm{C}$ for $2 \mathrm{~h}$. Suspensions were then washed twice by centrifugation and resuspended with $20 \mathrm{~mL}$ of BB. Three control and isopropanol treated replicates were performed for each strain. To confirm inactivation, suspensions were enumerated for CFU by spread plating $200 \mu \mathrm{L}$ onto five separate chocolate agar plates (BD Biosciences, USA) resulting in a LOD of $1 \mathrm{CFU} \mathrm{mL}^{-1}$. For control suspensions, the mean $\log _{10} \mathrm{CFU} \mathrm{mL} \mathrm{mL}^{-1} \pm \mathrm{SD}$ concentrations for LVS, IN99, and Schu4 were $6.9 \pm 0.1,7.0 \pm 0.0$, and $6.7 \pm 0.1$, respectively. CFU concentrations for all inactivated suspensions were $<$ LOD. For use in experiments, the inactivated cell suspensions were diluted (based on the concentrations of the respective strain's control suspensions) and added to samples to yield a final concentration of $10^{2}, 10^{4}$ or $10^{6}$ inactivated cells $\mathrm{mL}^{-1}$.

\section{Water quality analysis}

Drinking and well water samples were analyzed for free and total chlorine $\left(\mathrm{Cl}_{2}\right), \mathrm{pH}$, temperature, conductivity, percent dissolved oxygen (DO), hardness, and turbidity (Table 3) [41]. Measurements were made using DPD colorimetric analysis for free and total chlorine; a glass electrode $440 \mathrm{pH}$ meter (Corning ${ }^{\circledR}$ Electrochemistry Products) for pH; a YSI 566 Multi Probe System (YSI Environmental) for temperature, conductivity, and DO; ethylenediaminetetraacetic acid titration for hardness (Hach Company); and a portable 2100 Turbidimeter (Hach, USA) for turbidity. Additionally, water samples were submitted to the National Risk Management Research Laboratory at the US EPA in Cincinnati, OH to assay total organic carbon (TOC) (EPA Method 415.3 rev 1.1); trace metals (EPA Method 200.7); phosphate $\left(\mathrm{PO}_{4}\right)$ (EPA Method 365.1); and nitrate $\left(\mathrm{NO}_{3}\right)$ (EPA Method 353.2) (Table 3).

\section{Isolation and preparation of total DNA}

DNA was extracted from bacterial cells using the MasterPure $^{\mathrm{Tm}}$ Complete DNA purification kit (Epicentre Biotechnologies Inc., USA) according to manufacturer's protocol. The DNA pellet was resuspended in $50 \mu \mathrm{L}$ of molecular grade water. To remove PCR inhibitors from samples containing humic acid and ATD, an additional purification step was performed by using the OneStep ${ }^{\text {тм }}$ PCR Inhibitor Removal Kit (Zymo Research, USA) following manufacturer's protocols. Final DNA concentrations were measured with a Nanodrop ND-1000 Spectrophotometer (Thermo Scientific, USA) and analyzed as described below.

\section{Incubation of $F$. tularensis in the presence of each test matrix}

Ninety-six deep well polypropylene plates (Fisher Scientific, USA), with a working volume of $1.8 \mathrm{~mL}$ per well, were pre-loaded with a sterile $4 \mathrm{~mm}$ glass bead per well (to aid in aeration of the samples). In each well, $0.1 \mathrm{~mL}$ of the F. tularensis suspensions and $0.1 \mathrm{~mL}$ of suspensions containing either inactivated target cells, drinking water, well water, humic acid, or ATD (except for control wells), was added to $1.3 \mathrm{~mL}$ of $\mathrm{BVFH}$ in triplicate. For control wells, $0.1 \mathrm{~mL}$ of BB, sDW, sWW, or Milli$\mathrm{Q}^{\bullet}$, for the humic acid and ATD experiments, was used. Duplicate wells without bacteria $(0.1 \mathrm{~mL}$ of $\mathrm{BB})$ for each test matrix were also included. The final volume in each well was $1.5 \mathrm{~mL}$ where both bacterial cells and test matrix or controls were diluted 15-fold.

For each experiment, four 96-well plates were generated for each time point $(0,8,24$, and $48 \mathrm{~h})$ to minimize the loss of volume due to evaporation and sampling for culture and molecular analyses. After samples were added, plates were covered with an air-permeable AeraSeal $^{\mathrm{TM}}$ (Excel Scientific Inc., USA) and incubated at $37^{\circ} \mathrm{C}$ with shaking (Innova 42 shaker/incubator, New Brunswick Scientific, USA). After each time point, $1 \mathrm{~mL}$ from each well was transferred to $1.7 \mathrm{~mL}$ tubes, processed for DNA isolation, and analyzed by real-time PCR. The remaining volume (approximately $400 \mu \mathrm{L}$ ) in the well was used for CFU enumeration.

\section{PCR assay}

Forward (F) and reverse (R) primers and probe (Pr) used for Francisella detection were F: 5-AAC AAT GGC ACC TAG TAA TAT TTC TGG-3', R: 5' -CCA CCA AAG AAC CAT GTT AAA CC-3', and Pr: 5'FAM-TGG CAG AGC GGG TAC TAA CAT GAT TGG T-BHQ1 3' for fopA, an 87 base pair (bp) amplicon [16]; F: 5' GAG ACA TCA ATT AAA AGA AGC AAT ACC TT3', R: 5' - CCA AGA GTA CTA TTT CCG GTT GGT3', Pr: 5'FAM-AAA ATT CTG CTC AGC AGG ATT TTG ATT TGG TT-BHQ1 3'for pdpD, a 104 bp amplicon [15]; and F: 5' - CTT GTA CTT TTA TTT GGC TAC TGA GAA ACT-3', R: 5' - CTT GCT TGG TTT GTA AAT ATA GTG GAA-3', Pr: 5'FAM-AC CTA GTT CAA CCT CAA GAC TTT TAG TAA TGG GAA TGT CA-BHQ1 3'for ISFtu2, a 118 bp amplicon [15]. A total reaction volume of $20 \mu \mathrm{L}$ contained $10 \mu \mathrm{L} 2 \mathrm{x}$ TaqMan Universal Master Mix (Applied Biosystems, USA), $200 \mathrm{nM}$ primer concentrations, $6.4 \mathrm{nM}$ probe concentration, and $2 \mu \mathrm{L}$ total DNA. The thermal cycling conditions, performed on the QuantStudio ${ }^{\mathrm{Tm}} 6$ Flex Real-Time PCR System (ThermoFisher Scientific, USA) included a pre-denaturation step at $50^{\circ} \mathrm{C}$ for $2 \mathrm{~min}$ and $95^{\circ} \mathrm{C}$ for $10 \mathrm{~min}$; 45 cycles of denaturation at $95^{\circ} \mathrm{C}$ for $10 \mathrm{~s}$ and annealing and extension at $60{ }^{\circ} \mathrm{C}$ for $30 \mathrm{~s}$; and a final 
hold at $45^{\circ} \mathrm{C}$ for $5 \mathrm{~min}$. For initial confirmatory tests, 10-fold serial dilutions of $F$. tularensis KC1482 (Type A2 strain) and LVS (Type B strain) DNA ranging from 1 to $10^{7}$ cell equivalents $\mathrm{mL}^{-1}$ were used in the PCR assays and analyzed in triplicate to determine sensitivity of each gene assay.

The change in PCR cycle threshold $\left(\Delta C_{T}\right)$ which is calculated by subtracting the cycle threshold $\left(\mathrm{C}_{\mathrm{T}}\right)$ at time 0 $\left(C_{T 0}\right)$ from the $C_{T}$ value after incubation of samples in the culture medium $\left(\mathrm{C}_{\mathrm{Ti}}\right): \Delta \mathrm{C}_{\mathrm{T}}=\mathrm{C}_{\mathrm{T} 0^{-}} \mathrm{C}_{\mathrm{Ti}}$ [12]. This was annotated on the $\mathrm{x}$-axis as $\Delta \mathrm{C}_{\mathrm{T}}$ (T0-T8), $\Delta \mathrm{C}_{\mathrm{T}}$ (T0-T24), and $\Delta \mathrm{C}_{\mathrm{T}}$ (T0-T48). For the $\mathrm{T}_{0}$ cases where no PCR response was obtained (undetermined results), the $C_{T}$ values were set to 45 (since 45 PCR cycles were used). For detection of viable $F$. tularensis cells, a $\Delta C_{\mathrm{T}}$ value $\geq 6$ was chosen to indicate an increase in DNA concentration resulting from growth during the incubation period.

\section{Statistical analysis}

Statistical significance was determined with an unpaired, t test with corrections for multiple comparisons made using the Holm-Š́dák method. $P$ values $<0.05$ were considered statistically significant. For figures, data are expressed as mean with standard deviation. Statistical analyses and generation of graphs were performed using Prism 6 (GraphPad Software, USA).

\section{Supplementary information}

Supplementary information accompanies this paper at https://doi.org/10 1186/s12866-020-01748-0.

Additional file 1: SFigure. Control wells containing no live F. tularensis in the presence of inactivated target cells. Wells containing no live IN99 (A) or Schu4 (B) cells but 0 (circle), $10^{2}$ (square), $10^{4}$ (triangle), or $10^{6}$ (diamond) of the respective isopropanol inactivated target cells confirmed that treated cells were not viable and that no change in PCR signal was observed over time. Data are from three replicates and presented as mean $\Delta C_{T}$ values with error bars indicating standard deviation.

Additional file 2: STable. F. tularensis resting cell concentrations

\section{Abbreviations}

ATCC: American Type Culture Collection; ATD: Arizona Test Dust; BB: Butterfield's buffer; BEl: Biodefense and Emerging Infections Research Resources Repository; BVFH: Brain heart infusion broth supplemented with Vitox, Fildes, and histidine; CDC: Centers for Disease Control and Prevention; CFU: Colony forming units; $C_{T}$ : Cycle threshold; $\Delta C_{T}$ : Change in PCR cycle threshold; DO: Dissolved oxygen; DOC: Dissolved organic carbon; F: Forward; HIA: Heart infusion agar; HPC: Heterotrophic plate count; LOD: Limit of detection; LVS: Live Vaccine Strain; MPN: Most probable number; NIAID: National Institute of Allergy and Infectious Diseases; NIH: National Institutes of Health; $\mathrm{NO}_{3}$ : Nitrate; NTU: Nephelometric turbidity units; PCR: Polymerase chain reaction; $\mathrm{PO}_{4}$ : Phosphate; Pr: Probe; R: Reverse; R2A: Reasoner's 2A agar; RCF: Relative centrifugal force; SD: Standard deviation; sDW: Sterilized drinking water; sWW: Sterilized well water; TNTC: Too numerous to count; TOC: Total organic carbon; USEPA: United States Environmental Protection Agency

\section{Acknowledgements}

We would like to thank our USEPA colleagues, Mrs. Dana Macke for collecting and allowing us to use the well water from her farm, Mrs. Noreen
J. Adcock for her expertise and laboratory support, and Drs. Jim Goodrich and Hodon Ryu, for their technical review of this manuscript.

This manuscript has been subjected to the Agency's review and has been approved for publication. The views expressed in this article are those of the authors and do not necessarily represent the views or policies of the Agency. Mention of trade names, commercial products, and/or services does not imply an endorsement or recommendation for use by the U.S. Government or EPA.

\section{Authors' contributions}

ER conceived and designed the work. $\mathrm{HB}$ and BM performed the experiments and collected the data. HB analyzed and interpreted the data and wrote the manuscript. All authors read and approved the final manuscript.

\section{Funding}

The U.S. Environmental Protection Agency (EPA) through its Office of Research and Development funded and managed the research described herein under contract \# EP-C-11-006 to Pegasus Technical Services, Inc. With EPA funding, federal researchers and contractors designed the study; collected, analyzed, and interpreted the data; and wrote the manuscript.

Availability of data and materials

Data generated for this study is publicly available as per U.S. EPA policy.

Ethics approval and consent to participate

Not applicable.

\section{Consent for publication}

Not applicable.

\section{Competing interests}

The authors declare that they have no competing interests.

\section{Author details}

1 US EPA, Office of Research and Development, Center for Environmental Solutions \& Emergency Response, 26 W Martin Luther King Drive NG-16, Cincinnati, OH 45268, USA. ${ }^{2}$ Pegasus Technical Services, Inc c/o US EPA, Cincinnati, OH, USA.

Received: 13 November 2019 Accepted: 6 March 2020

Published online: 25 March 2020

\section{References}

1. Pedati C, House J, Hancock-Allen J, Colton L, Bryan K, Ortbahn D, et al. Notes from the field: increase in human cases of tularemia - Colorado, Nebraska, South Dakota, and Wyoming, January-September 2015. MMWR Morb Mortal Wkly Rep. 2015;64(47):1317-8.

2. Carvalho CL. Lopes de Carvalho I, Zé-Zé L, Núncio MS, Duarte EL: Tularaemia: a challenging zoonosis. Comp Immunol Microbiol Infect Dis. 2014;37(2):85-96.

3. Oyston PC. Francisella tularensis: unravelling the secrets of an intracellular pathogen. J Med Microbiol. 2008;57(Pt 8):921-30.

4. Sjöstedt A. Tularemia: history, epidemiology, pathogen physiology, and clinical manifestations. Ann N Y Acad Sci. 2007:1105:1-29.

5. Svensson K, Bäck E, Eliasson H, Berglund L, Granberg M, Karlsson L, et al. Landscape epidemiology of tularemia outbreaks in Sweden. Emerg Infect Dis. 2009;15(12):1937-47.

6. Rice EW. Occurrence and control of tularemia in drinking water. J Am Water Works Ass. 2015;107(10):E486-96.

7. Johansson A, Celli J, Conlan W, Elkins KL, Forsman M, Keim PS, et al. Objections to the transfer of Francisella novicida to the subspecies rank of Francisella tularensis. Int J Syst Evol Microbiol. 2010;60(Pt 8):1717-8 author reply $1718-1720$

8. Busse HJ, Huber B, Anda P, Escudero R, Scholz HC, Seibold E, et al. Objections to the transfer of Francisella novicida to the subspecies rank of Francisella tularensis - response to Johansson et al. Int J Syst Evol Microbiol. 2010;60(Pt 8):1718-20.

9. Kugeler KJ, Mead PS, Janusz AM, Staples JE, Kubota KA, Chalcraft LG, et al. Molecular epidemiology of Francisella tularensis in the United States. Clin Infect Dis. 2009;48(7):863-70. 
10. Petersen JM, Schriefer ME. Francisella. In: Manual of clinical microbiology 11th ed. Washington, DC: ASM Press; 2015. p. 851-62.

11. 42.CFR.§73: Federal Select Agents Program: Select Agents and Toxins, Title 42 Public Health, Code of Federal Regulations Part 73. http://www. selectagentsgov/SelectAgentsandToxinsListhtm/ 2015.

12. Létant SE, Murphy GA, Alfaro TM, Avila JR, Kane SR, Raber E, et al. Rapidviability PCR method for detection of live, virulent Bacillus anthracis in environmental samples. Appl Environ Microbiol. 2011;77(18):6570-8.

13. Morris BJ, Buse HY, Adcock NJ, Rice EW. A novel broth medium for enhanced growth of Francisella tularensis. Lett Appl Microbiol. 2017;64(6): 394-400.

14. Kane SR, Shah SR, Alfaro TM. Rapid viability polymerase chain reaction method for detection of Francisella tularensis. J Microbiol Methods. 2019; 166:105738.

15. Kugeler KJ, Pappert R, Zhou Y, Petersen JM. Real-time PCR for Francisella tularensis types $a$ and B. Emerg Infect Dis. 2006;12(11):1799-801.

16. Emanuel PA, Bell R, Dang JL, McClanahan R, David JC, Burgess RJ, et al. Detection of Francisella tularensis within infected mouse tissues by using a hand-held PCR thermocycler. J Clin Microbiol. 2003;41(2):689-93.

17. Ahlinder J, Öhrman C, Svensson K, Lindgren P, Johansson A, Forsman M, et al. Increased knowledge of Francisella genus diversity highlights the benefits of optimised DNA-based assays. BMC Microbiol. 2012;12(1):12.

18. Kane SR, Shah SR, Alfaro TM. Development of a rapid viability polymerase chain reaction method for detection of Yersinia pestis. J Microbiol Methods. 2019;162:21-7.

19. Schmittgen TD, Livak KJ. Analyzing real-time PCR data by the comparative C(T) method. Nat Protoc. 2008;3:1101

20. Lauriano CM, Barker JR, Yoon SS, Nano FE, Arulanandam BP, Hassett DJ, et al. MglA regulates transcription of virulence factors necessary for Francisella tularensis intraamoebae and intramacrophage survival. Proc Natl Acad Sci U S A. 2004;101(12):4246-9.

21. Ludu JS, de Bruin OM, Duplantis BN, Schmerk CL, Chou AY, Elkins KL, et al. The Francisella pathogenicity island protein $\mathrm{PdpD}$ is required for full virulence and associates with homologues of the type VI secretion system. J Bacteriol. 2008;190(13):4584-95

22. Nano FE, Schmerk C. The Francisella pathogenicity island. Ann N Y Acad Sci. 2007;1105:122-37.

23. Opel KL, Chung D, McCord BR. A study of PCR inhibition mechanisms using real time PCR. J Forensic Sci. 2010;55(1):25-33.

24. Volk C, Wood L, Johnson B, Robinson J, Zhu HW, Kaplan L. Monitoring dissolved organic carbon in surface and drinking waters. J Environ Monit. 2002;4(1):43-7.

25. France B, Bell W, Chang E, Scholten T. Composite sampling approaches for Bacillus anthracis surrogate extracted from soil. PLoS One. 2015;10(12): e0145799.

26. Park J, Jang M, Yu Z. Heterogeneous photo-oxidation of SO2 in the presence of two different mineral dust particles: Gobi and Arizona dust. Environ Sci Technol. 2017;51(17):9605-13.

27. Rodes CE, Newsome JR, Vanderpool RW, Antley JT, Lewis RG. Experimental methodologies and preliminary transfer factor data for estimation of dermal exposures to particles. J Expo Sci Environ Epidemiol. 2001;11(2):123-39.

28. Wan W, Yeow JTW, Van Dyke M. Effect of silver and titanium dioxide nanoparticles on PCR efficiency. In: 9th IEEE conference on nanotechnology 2009. Genoa: Institute of Electrical and Electronics Engineers (IEEE). 2009. p. 458-61.

29. Combs LG, Warren JE, Huynh V, Castaneda J, Golden TD, Roby RK. The effects of metal ion PCR inhibitors on results obtained with the Quantifiler(R) human DNA quantification kit. Forensic Sci Int Genet. 2015;19: 180-9.

30. Wang W, Wang HB, Li ZX, Guo ZY. Silicon inhibition effects on the polymerase chain reaction: a real-time detection approach. J Biomed Mater Res A. 2006;77(1):28-34.

31. Rose LJ, Hodges L, O'Connell H, Noble-Wang J. National validation study of a cellulose sponge wipe-processing method for use after sampling Bacillus anthracis spores from surfaces. Appl Environ Microbiol. 2011;77(23):8355-9.

32. Adcock NJ, Morris BJ, Rice EW. Acid resistance in Francisella tularensis. Microbiologyopen. 2014;3(1):133-8.

33. Humrighouse BW, Adcock NJ, Rice EW. Use of acid treatment and a selective medium to enhance the recovery of Francisella tularensis from water. Appl Environ Microbiol. 2011;77(18):6729-32.
34. Staples JE, Kubota KA, Chalcraft LG, Mead PS, Petersen JM. Epidemiologic and molecular analysis of human tularemia, United States, 1964-2004. Emerg Infect Dis. 2006;12(7):1113-8.

35. Camper AK. Coliform regrowth and biofilm accumulation in drinking water systems: a review. In: Geesey GG, Lewandowski Z, Flemming HC, editors. Biofouling and biocorrosion in industrial water systems. Bozeman, MT, USA. Lewis Publishers; 1993. p. 91-105.

36. Bourdon LD, Liggett J, Sidari FP III, Triantafyllidou S. Preventing disease from Legionella is a shared responsibility. Opflow. 2019;45(2):10-3.

37. Miles AA, Misra SS, Irwin JO. The estimation of the bactericidal power of the blood. J Hyg (Lond). 1938;38(6):732-49.

38. Gaudy AF Jr, Abu-Niaaj F, Gaudy ET. Statistical study of the spot-plate technique for viable-cell counts. Appl Microbiol. 1963;11:305-9.

39. Hoben HJ, Somasegaran P. Comparison of the pour, spread, and drop plate methods for enumeration of Rhizobium spp. in inoculants made from presterilized peat. Appl Environ Microbiol. 1982;44(5):1246-7.

40. Rice EW, Scarpino PV, Logsdon GS, Reasoner DJ, Mason PJ, Blannon JC. Bioassay procedure for predicting coliform bacterial growth in drinking water. Environ Technol. 1990;11:821-8.

41. Rice EW, Baird EB, Eaton AD. Standard methods for the examination of water and wastewater, 23rd edition. 23rd ed. Washington, DC: American Water Works Association and Water Environment Federation; 2017.

\section{Publisher's Note}

Springer Nature remains neutral with regard to jurisdictional claims in published maps and institutional affiliations.
Ready to submit your research? Choose BMC and benefit from:

- fast, convenient online submission

- thorough peer review by experienced researchers in your field

- rapid publication on acceptance

- support for research data, including large and complex data types

- gold Open Access which fosters wider collaboration and increased citations

- maximum visibility for your research: over $100 \mathrm{M}$ website views per year

At BMC, research is always in progress.

Learn more biomedcentral.com/submissions 